\title{
小児上腕骨顆上骨折の治療成績
}

\author{
山口曰赤病院整形外科

石 崎 知 樹・張懐 仁

山本緑・福風善平

\section{Supracondylar Fractures of the Humerus}

- Treatment by sponge traction and Result

by

\section{T. Ishizaki, H. Chang, M. Yamamoto and Y. Fukuoka}

Orthopedic Clinic, Yamaguchi Red Cross Hospital, Yamaguchi, Japan

\begin{abstract}
In a retrospective survey of forty-three patients with supracondylar fractures of the humerus, nineteen children were examined clinically and roentgenographically at follow up.

Eleven cases were treated by traction, with the shoulder in a position 110 degrees of abduction and 40 degrees of anterior elevation and the elbow in a position 20 to 30 degrees short of full extension.

Initial displacement and the adequacy of the reduction were correlated with the varus deformity at follow up.
\end{abstract}

\section{はじめに}

小児上腕骨顆上骨折は，日常多く遭遇する骨折で， 最近中高年にあ見られるが，尚，小児の骨折之言って む過言ではない，その治療として，非観血的治療が一 般とされているが, 尚, 観血的治療も行われている. 我々はダンロップ毫引に工夫を加えた治療を主として 行なったので報告する.

\section{症例}

昭和 39 年より昭和 53 年までに, 当科で治療した上 腕骨顆上骨折は 43 例であり, その内訳は, 成人 3 例, 小児 40 例である. 整復不能例 1 例之神経 麻㾝を伴な った 2 例のみが，手術をうけているが，他の 37 名は 非観血的治療をうけている.

今回報告の対象となる直接検診した小児上腕骨顆上 骨折は 19 例であり, 男 11 例, 女 8 例, 右側 8 例, 左 側 11 例である. 受傷時年令は, 最低 1 才 10 力月, 最 高 13 才 4 力月で平均 6 才 3 力月である. 合併症は橈
骨神経麻㾝 2 例, 正中神経麻㾝 1 例で全て 2 力月以内 に回復している，血管障害，Volkmann 拘縮の例は ない.

\section{治療法}

まず神経血管障害の有無を確かめ, 無麻酔で俥い徒 手整復を行ない, その後, スポンジ牽引を行なった。 肩関節外転 $110^{\circ}$, 前方挙上約 $40^{\circ}$ の俥圣い届曲位で, 約 $2 \sim 3 \mathrm{~kg}$ の毫引を行なった. 肩関節外転位とする ことにより, 内反変形を矯正し, 前方挙上により, 過 伸展を防ぐ目的である. その後レ線をとり，健側の Baumann 角之比較し, 内反位のものは下方に, 過伸 展のものは後方に $0.2 \sim 0.5 \mathrm{~kg}$ の補助率引を行なっ た. 数日後, 矯正不充分な時は, 铑引のまま軽い徒手 整復を試みた. 牽引期間は約 3 週であり，なお，仮骨 形成が不充分なすのは, ギブスシーネを軽度屈曲位で 行なった. 後療法は全く自動運動に任せた. 


\section{治 療 成 績}

対象となった小览上腕骨顆上骨折 40 例のうち, 今 回直接検診した小夰上腕骨顆上骨折は 19 例であり， 铄引療法を行なったものは11例であった， ROM の 減少について述べると，伸屈制限をきたしたものはな く, 屈曲制限 $10^{\circ}$ 以上のものは 1 例 ( $15^{\circ}$ の減少) の みであり, 何ら ADL に差し仕えない. 内反変形をき

表1レントゲンにおける骨片の転位

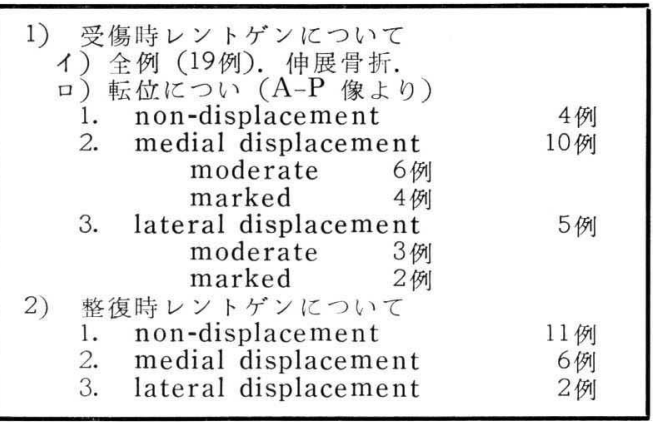

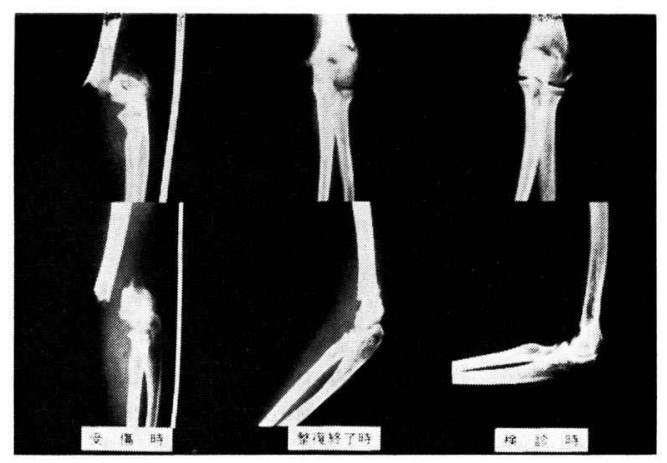

図 1

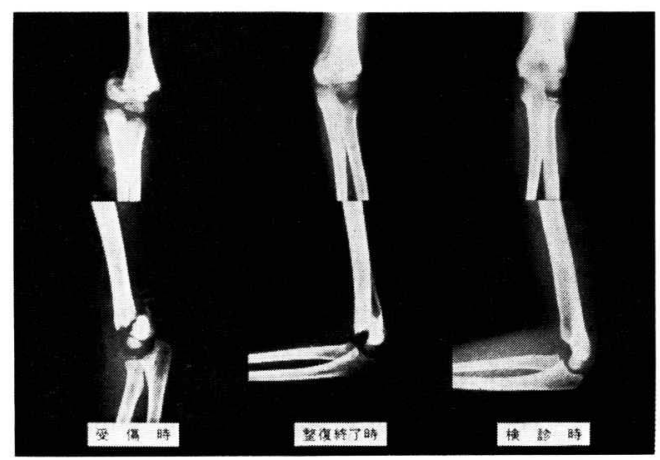

図 2
たしたものは 19 例中 6 例で, 最高 $10^{\circ}$ の内反最低 $2^{\circ}$ の内反で平均 $6.7^{\circ}$ の内反変形をきたした.

1）受傷時レ線について（表 1 ）

全例伸展骨折であり，転位のないもの4例，内側転 位 10 例, 外側転位 5 例であり, 内反変形との相関を みると，転位のないグループは一例も内反変形をきた していない. 内側転位のグループは 10 例中 6 例に内 反変形をみる. 外側転位のグループは, 一例あ内反変 形をきたさず，また外反変形もきたしていない，

2）整復時レ線について（表 1 ）

内外側転位のない例 11 例, 内側転位 6 例, 外側転 位 2 例であり, 内外変形との相関をみると, 転移のな いグループは 1 例のみ $8^{\circ}$ の内反変形をきたしている が, 残り 10 例は良好な結果を得ている. この 1 例は, 整復終了時既に $8^{\circ}$ の内反変形をきたしており，横軸 転位はなかった例であった. 内側転位の残ったグルー プは 6 例で, 1 例を除いて全て内反変形をきたした. 外側転位の残ったグループは 2 例で，2例ともに内反 変形をきたしていない。

\section{症例 110 才 6 力月，女子（訹 1 )}

木梢骨片は上腕骨との接触もなく，著明に後方へ転 位する. 全麻下徒手整復後, スポンジ旁引 15 日, ギ ブスシーネ 21 日間施行, 整復終了時レ線上 $4 \mathrm{~mm}$ の 内側転位を残す。検診時, 肘関節可動制限はないが, 約 $5^{\circ}$ の内反変形をきたす.

症例 27 才, 男子(図 2 )

木梢骨片は後内側に転位をきたす。無麻酔にて軽い 徒手整復後, スポンジ钼引 4 週間施行. 整復終了時レ 線上: $7 \mathrm{~mm}$ の内側転位を残す. 検診時伸展制限はな く, $140^{\circ}$ の届曲可能, 外反角は $5^{\circ}$ にて, 内反变形は きたしていない、内側転位が残るも内反変形をきたさ なかった唯一の症例である。

症例 3 才, 男子(図 3 )

受傷時転位は殆んよ゙なく，過伸展に対し軽く徒手整 復を加え，旁引16日を施行した例である。転位が少 ないので内外反もないと考えていたが，検診時 $6^{\circ}$ の 内反を示していた：二次性に発生した内反肘ではない かと考えていたが，整復終了時のレ線を改めてみる と，同じ程度の内反を示していた，転位が少なくても 健側レ線と十分比較しながら治療すべきと反省せしめ られた 1 例である。 


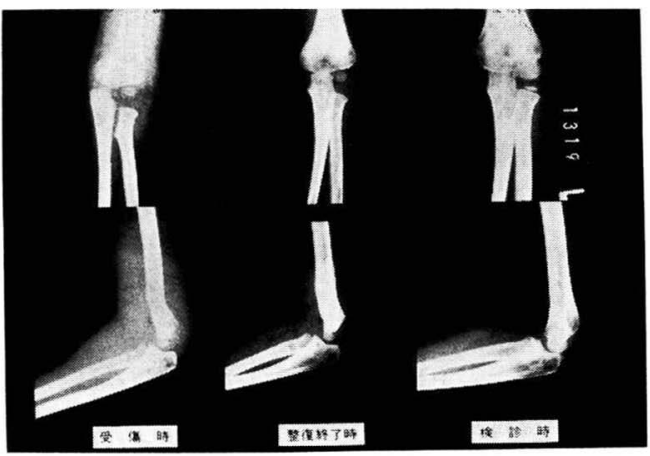

図 3

考

案

上腕骨顆上骨折の牽引療法には, Dunlop 牽引法, 前田式垂直率引法, 时屈曲持続辁引法など, いろいろ あるが，大切なことは，如何にして正しく整復し，整 復位を保つかということである．我々は，肩関節外転 $110^{\circ}$, 前方挙上約 $40^{\circ}$ で, 时関節は軽い屈曲位で育引 を行なった，肩関節外転 $110^{\circ}$ とすることにより，内 反変形を防止するのではないかと考えたわけである. また，时関節の軽い屈曲位は，骨折部の前方凸屈曲変 形の予防のためである.

牽引開始後 $2 \sim 3$ 日して, 整復が不充分な場合は, 牽引のまま徒手整復を試み, より正確な整復を得, 内 反あるいは前方凸屈曲の変形を防止するために補助弃 引を加えた。

我々の治療法は, 患部の腫脹を最小限にとどめ, 軟 部組織の損傷を少なくし, 経時的レ線変化の観察を容 易にする. また, 米引のまま徒手整復が容易に行なわ れる特長がある. しかし, 基本的に重要なととは正確 な整復である. Watson-Jones, Dodge 等は, スポ ンジ铄引のみでは正確な整復は得られ難く, 正確な徒 手整復が必要であり, その保持として, 牽引療法が役 立つといっている.

我々は，正確な整復ができたものはギブス固定を行 なっているが, 正確な整復が困難なものは, 牽引療法 により, また, 徒手整復を加えて, 内外反変形および 前方凸屈曲変形の防止を行なった. ADL に何等障害 を残していない.

今回の調査結果より, 受傷時レ線上内側転位をきた したものは内反変形をきたし易く, また, 転位の矯正 が十分に行なわれず, 軽度の内側転位を残したあのに
内反変形が多かった．したがって内反変形予防のため には,できるだけ早期に内側転位を残さないように， 整復操作を行ない，仮骨ができるまで，牽引を行なう 必要があると考える.

\section{ま と め}

1. 徒手整復後, 肩関節外転 $110^{\circ}$ 届曲位で, スポ ンジ挛引を行なった.

2. 受傷時レ線上内側転位のある症例は, 内反変形 をきたし易い。

3. 受傷時レ線上外側転位のある症例は，5例とも に内外反変形をきたしていない.

4. 整復終了時レ線上内側転位を残したものは， 6 例中 5 例に内反変形をきたした.

5. 後療法はすべて自動運動に任せたが， $15^{\circ}$ の屈 曲制限を残すむの 1 例のみで，全例 ADL に支障はな い.

\section{参考文 献}

1) Arnold, J. A. et al.: Supracoudylarfractures of the humerus. J. Bone and Joint Surg. 59-A : 589-595, 1977.

2) Beals, R. K. : The Normal Carrying Angle of the Elbow. Clin. Orthop. 119, 1976.

3) D'ambrosia, R. D. : Supracoudylar fracture of the humerus, prevention of cubitus varus. J. Bone and Joint Surg. 54-A : 6066, 1972.

4) Dodge, H. S. : Displaced supracondylar fractures of the humerus in childrenTreatment by Dunlop's traction. J. Bone and Joint Surg. 54-A: 1408-1418, 1972.

5)池田他夫 - 他：上腕骨顆上骨折の治療, 整形外 科, $20: 477 \sim 481,1969$.

6) 井上博, 宮城恒夫: 时屈曲持続制引療法, 災 害医学, 21:323-334, 1978.

7) 児玉利武 - 他：外傷性内反时の成因, 整形外 科, 13: 905 911, 1962 .

8）前田和三郎, 野崎寛三：新鮮なる小児上膊骨顆 上骨折, 垂直牽引療法（前田氏法）に就て, 日整 会誌，11：521～546，1937.

9）杉浦良雄：小児上腕骨顆上骨折の保存的治療, 災害医字, 21: 893-900, 1978.

10) Watson-Jones, R. : Fractures and Joint Injuries, 5th ed., Livingston, Ediburgh, 1976.

11) 神中正一：神中整形外科学, 南山堂, 東京, 
1972.

回 答

1）治療法は同じなため, 上位型, 下位型と分類し

山口日赤 石崎 知樹
ていない.

2) Slipping Epiphysis の例はない. 